\title{
Editorial: On IRIE Vol. 21
}

We all remember Plato's famous media critique of writing in his Phaedrus (274-275):

\begin{abstract}
But when they came to letters, This, said Theuth, will make the Egyptians wiser and give them better memories; it is a specific both for the memory and for the wit. Thamus replied: 0 most ingenious Theuth, the parent or inventor of an art is not always the best judge of the utility or inutility of his own inventions to the users of them. And in this instance, you who are the father of letters, from a paternal love of your own children have been led to attribute to them a quality which they cannot have; for this discovery of yours will create forgetfulness in the learners' souls, because they will not use their memories; they will trust to the external written characters and not remember of themselves. The specific which you have discovered is an aid not to memory, but to reminiscence, and you give your disciples not truth, but only the semblance of truth; they will be hearers of many things and will have learned nothing; they will appear to be omniscient and will generally know nothing; they will be tiresome company, having the show of wisdom without the reality.
\end{abstract}

Most interestingly, Plato's major concern is not the detrimental impact of this new technique of writing on science, religion or the state. It is its impact on education that worries him most. He does not dispute that truth can also be expressed probably even better in written, he doubts that this way of expressing the truth is useful in the area of leading disciples to its very understanding.

Maybe, one reason for his concern can be pointed out best by taking a look at the original meaning of the notion of education stemming from the Latin word 'educatio' meaning 'leading out'. To educate in that sense does mean less 'pointing to' an insight, some facts or even a truth - what media could accomplish perfectly and the more advanced the media is the more advanced its execution of this task can be assumed - but leading away from the shelter of youth, ignorance and traditional truths that have to be overcome. That truly needs something different: personal interaction and individual guidance on a way nobody knows where it will lead to. Thus education in this sense is the very opposite of 'informatio' - the other Latin term often used for education indeed emphasizing more the bringing into a desired shape using the respective techniques of which writing (and other media) are (excellent) ones.

Now, what is exciting about digital media in education (at least since web 2.0) is that it combines the unprecedented expressiveness of multimedia with the interactivity of the net on a personal as well as on large scale. Thus in fact, it was not the radio that revolutionized formation (as it was expected by many in the beginning of the 20th century) and also not TV so far. Maybe because they have the same deficits in common that Plato already attributed to writing. And maybe, with the invention and fusion of digital media and the internet, everything will be different? In this issue, you finally won't find a digital answer to this question - a pure 'yes' or 'no' - but some fine balancing of the tremendous opportunities and the inherent risks.

Yours,

the editors. 